\title{
物理モデルを用いた蓄熱槽の異常検知に関する研究 FAULT DETECTION IN THERMAL STORAGE TANK USING PHYSICAL MODEL
}

\author{
相良和 伸* \\ Kazunobu SAGARA
}

\begin{abstract}
A method of fault detection in thermal storage tank and results of applying to data which are generated by simulation and are obtained from an actual thermal storage system are presented. In the fault detection, a physical model is used for a water thermal storage tank of multi-connected complete mixing type, and unknown parameters of the physical model are identified from mearied data. Faults can be detected by comparing value of identified parameters with value of the identified parameters under normal condition. In this report, simulation study was conducted in which several faults in storage tank, such as insulation damage of tank wall or abnormal water level in tank, were tried to detect. Furthermore, an analysis of identified parameters of the model is presented for measured data in an actual system.
\end{abstract}

Keywords: Fault detection, Thermal storage tank, Physical model, Multi-connected complete mixing tank, Simulation, Actual system

異常検知、蓄熱槽、物理モデル、連結完全混合槽型、シミュレーション、実システム

\section{1.はじめに}

建築設備は技術の進歩とともにますます複雑なものと なり、システムに異常が発生したときに設備管理者の対 応が困難となってきているとともに、熟練技術者の確保 も困難となりつつある。システムに異常が発生したまま で運転を継続する.と機器の損傷に至るというだけでなく、 快適環境の実現と省エネルギーを追及した設計であった としても、そのせっかくの性能が活かされないことにな る。このような事態に備えて、末熟な設備管理者であっ てもシステムの異常が発生した場合に即座に対応できる ように、設備管理システムの中に異常検知・診断支援シ ステムを組み込む試みがなされてきている1),2),3)。

住宅・建築省エネルギー機構 B E M S 委員会により、 1992 年 8 月に空調設備設計技術者 25 人を対象として、蓄 熱システムに関する種々の異常の中から重大であると考 えられる異常を選択する形式のアンケート調查 ${ }^{4}$ が実施
されている。その結果によれば、重大と判定された異常 の上位 3 位に槽防水異常、槽断熱異常、槽容量過小が挙 げられている。他にポンプ・配管系、制御系の異常が挙 げられているが、防水・断熱の異常は、その影響が急激に 現れないために通常の手段では検知することが困難であ ることが重大な異常として選択された大きい理由となっ ている。

システムの異常を検知する方法として最も単純な方法 は、温度や流量などの計測值がある範囲を外れたときに アラームを発するものであるが、一般には運転条件に応 じてこれらの状態は変化するためにその範囲を定めるの は困難である。運転条件の変化を考慮した方法としては、 入力に対する出力の正常時における関係をモデル化し、 そのモデルの出力と異なる計測值が得られたときに異常 と判定する方法がある。さらに、計測データからモデル のパラメータを同定することにより、正常時のパラメー

\footnotetext{
$*$ 三重大学工学部建築学科 教授・工博
} 
タ值と異なるパラメータ值が得られたときに機器の特性 が何らかの異常により変化したとして異常を検知する方 法があり、この場合には単に異常の検知だけでなく、異 常原因に関する情報を得ることも可能となる4)。モデル としては、物理モデルを利用する場合とARMAモデル のような時系列モデルを利用する場合があるが、可能で あれば物理モデルを利用した方が同定されるパラメータ が物理的な意味を持っていることから異常原因の診断が 容易であると考えられる。

本研究では、連結完全混合槽型蓄熱槽を用いた蓄熱シ ステムに関して、蓄熱槽自身の断熱材や水位の異常を自 動的に検知することを目的として、蓄熱槽の物理モデル のパラメータを計測データから同定することにより、そ の動特性の変化を検知して異常診断を行う方法をシミュ レーションにより检討した結果を示すとともに、実蓄熱 システムの計測データを用いてパラメータ同定を行った 結果を示した。

$\because 6$

\section{2.蓄熱槽の物理モデル}

連結完全混合槽型蓄熱槽は、槽内が完全混合状態であ る槽が直列に連結されていることにより、蓄熱槽全体と して高温水と低温水の分離を図ろうとするものである が、ここでのモデルでは死水域および槽壁との熱のやり 取りを考慮し、以下の仮定によりモデル化した。

- 各槽内において、流入水は蓄熱に有効な部分で完全 混合し、死水域は蓄熱に全く関与しないものとする。

- 各槽での有效部分の水温の水が次槽人流入するもの とする。

- 水の密度と比熱は水温に伡存しないものとする。

- 槽内の水と槽壁との熱のやり取りは、壁体とのサイ クリックな吸放熱に関係する部分と定常的に熱がー 方向に流れる部分とに分離できるものとする。

また、槽内の蓄熱に有効な部分の比率を有効容積率 $P$ と しているが、ここでは水位が低下した場合にも有効な部 分の容積が減少したものとみなすこととする。

以上の仮定から、 $N$ 槽から構成される蓄熱槽の第 $i$ 槽に おける水温は次式に支配されるとした。

$$
\rho c_{p} P_{i} V_{i} \frac{d \theta_{i}}{d t}=\rho c_{p} Q\left(\theta_{i-1}-\theta_{i}\right)+U_{i} A_{i}\left(\theta_{a m b, i}-\theta_{i}\right)+q_{i} A_{i}(1)
$$
ここで、

$$
\theta_{0}=\theta_{i n}, \quad V_{t}=\sum_{i=1}^{N} V_{i} \quad(i=1, \cdots, N)
$$

である。ただし、配管系の設計によっては、低温側端槽 と高温側端槽で冷凍機や空調機からの入力と隣槽からの 入力が同時に発生する場合があり、その場合には(1)式右
辺第 1 項が入力の数だけ必要となる。右辺第 2 項は、壁 体とのサイクリックな吸放熱に関係する部分であり、一

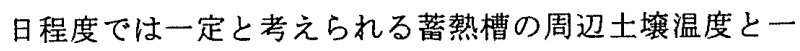
日周期でサイクリックに変動する槽内温度との温度差に よる吸放熱を表しており、ここでは、周辺土鋁温度 $\theta_{a m b, i}$ は槽内水温 $\theta_{i}$ の一日の平均温度に等しいとした。右辺第 3 項は、定常的に熱が一方向に流れる部分であり、機械 室などに接した蓄熱槽の天井部分からの定常的な熱流お よび実際の周辺土壌温度と $\theta_{a m b, i}(=$ 槽内日平均水温）と の差による熱流を代表しているとした。

異常検知においては、このモデル式の 3 個のパラメー 夕 $\left(P_{i} \cdot U_{i} A_{i} \cdot q_{i} A_{i}\right)$ を同定することとする。

\section{3. 物理モデルのパラメータ同定と異常検知}

個々の槽全てについて 3 個のパラメータを同定するた めには、全ての槽で水温が測定されている必要があるが、 見実には蓄熱制御などに必要な数筍所の槽のみで測定さ れているのが一般的であるため、ここでは、一部の槽内 温度の測定值からパラメータ同定を可能とするために、 パラメータ值が全分割槽で同じ值である $\left(P_{i}=P, U_{i} A_{i}=\right.$ $\left.U A, q_{i} A_{i}=q A\right)$ とし、蓄熱槽全体で 3 個のパラメータ $(P, U A, q A)$ を同定することとする。パラメータの同定に おいては、測定された入力条件下でモデルを用いたシミュ レーションを行い、測定槽の水温との誤差の 24 時間の積 算值が最小となるように、最小值探索アルゴリズムの一 つである修正 Powell 法5)を用いてパラメータの值を求め る。具体的な手順は以下の通りである。

1. 全ての槽の初期温度（午前 0 時）を測定されている 槽内温度から内挿する。

2. モデルのパラメータの初期值をセットする。ここで は、 $P=1.0 、 U A=q A=0.0$ としている。

3. 一日分の測定された入力温度と流量の条件下におけ るシミュレーションを行う。

4. 測定されている槽での測定水温と計算水温との一日 分の自乗誤差を積算する。

5. 修正Powell 法を用いて、誤差が最小になる方向に新 しいP, $U A, q A$ の值を決める。

上記の手順に沿って、最小誤差が得られるまで $3 \sim 5$ を繰 り返すことにより、1 日分のデータから $P, U A, q A$ が 1 個づつ同定できることになる。そして、毎日の同定パラ メータ值を蓄積していくことにより、異常が発生した日 （異常日）には同定パラメータ值がこれまでの正常日の パラメータ值と異なる值となることから異常検知できる ことになる。 


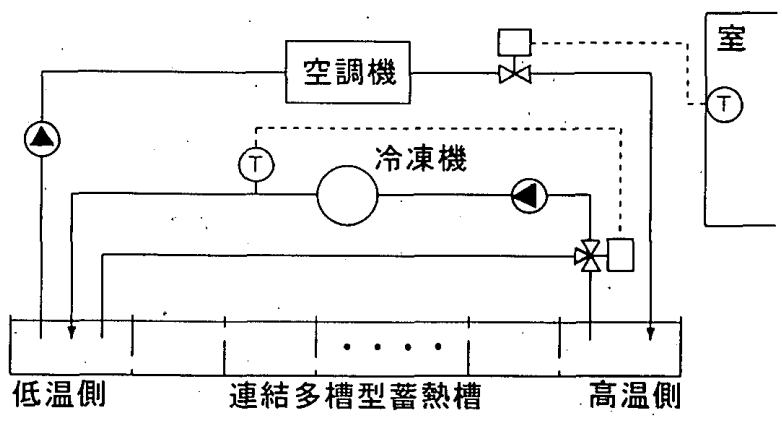

図 1 想定蓄熱システムの概要

表 1 想定蓄熱システムの条件

\begin{tabular}{ll}
\hline 蓄熱槽容量 & $400 \mathrm{~m}^{3}$ \\
分割槽数 & 26 \\
外周槽壁断熱材厚さ & $50 \mathrm{~mm}$ \\
冷凍機容量 & $125 \mathrm{Mcal} / \mathrm{h}$ \\
冾凍機側流量 & $25 \mathrm{~m}^{3} / \mathrm{h}$ \\
標準泠凍機出口温度 & $6^{\circ} \mathrm{C}$ \\
冷凍機出入口温度差 & $5^{\circ} \mathrm{C}($ 一定 $)$ \\
空調機出入口温度差 & $7{ }^{\circ} \mathrm{C}($ 一定 $)$ \\
測定槽内温度 & 8 点 \\
測定時間間隔 & 1 時間 \\
\hline
\end{tabular}

4. シミュレーションによる異常検知の検討

連結完全混合槽型蓄熱槽と冷凍機、空調機から構成さ れる図1および表1に示した蓄熱システムを想定し、シミ ユレーションにより正常時と異常時のデータを生成して 断熱材異常などの診断を試みた。

蓄熱槽の断熱は、槽天井・底部・外周のみとし、隔壁に は設けないこととした。また、ここでは冷凍機出口温度 が $6{ }^{\circ} \mathrm{C}$ 一定となるように入口三方弁を制御しているとし、 入口温度が変化しても冷凍機の能力変化を無視して出入 口温度差を $5{ }^{\circ} \mathrm{C}$ 一定とした。空調機についても流量增減 によるコイル特性を無視して常に一定出入口温度差 $7^{\circ} \mathrm{C}$ とした。

\section{（1）データ生成のための蓄熱槽物理モデル}

各槽の 6 面の槽壁における熱流を考虑して、有効容積 部分で完全混合する $N$ 個の槽からなる蓄熱槽の第 $i$ 槽の 槽内水温が次式で表されるとする。

$$
\rho c_{p} P_{i} V_{i} \frac{d \theta_{i}}{d t}=\rho c_{p} Q\left(\theta_{i-1}-\theta_{i}\right)+\sum_{j=1}^{6} q_{i j} A_{i j}
$$

パラメータ同定用の物理モデルとの違いは、槽壁との熱 のやり取りの部分であり、データ生成用のモデルでは槽 壁内部で一次元熱伝導を仮定し、より現実に近い熱流計 算を行った。

シミュレーションでは、各槽の各槽壁（側壁・天井・底 部）毎に、上式を差分化して槽壁内部温度および壁面熱 流を求めた。槽壁熱流計算の際の境界条件は以下.の通り とした。
表 2 槽壁熱流計算に用いた各種熱定数

\begin{tabular}{|c|c|c|c|}
\hline & $\begin{array}{c}\text { 熱伝導率 } \\
\mathrm{kcal} /\left(\mathrm{m} \cdot \mathrm{h} \cdot{ }^{\circ} \mathrm{C}\right)\end{array}$ & $\begin{array}{l}\text { 温度拡散率 } \\
\times 10^{-3} \mathrm{~m}^{2} / \mathrm{h}\end{array}$ & $\begin{array}{l}\text { 熱伝導抵抗 } \\
\mathrm{m}^{2} \cdot \mathrm{h} \cdot{ }^{\circ} \mathrm{C} / \mathrm{kcal}\end{array}$ \\
\hline \multirow{5}{*}{$\begin{array}{l}\text { コンクリート } \\
\text { 土壌 } \\
\text { 断熱材 } \\
\text { 空気層 }\end{array}$} & \multirow{5}{*}{$\begin{array}{c}1.3 \\
0.50 \\
0.032\end{array}$} & 3.0 & \\
\hline & & 1.4 & \\
\hline & & (フォームオ & リスチレン) \\
\hline & & （下向き熱流） & 0.30 \\
\hline & & （上向き熱流） & 0.20 \\
\hline
\end{tabular}

- 槽壁内部表面温度は槽内水温に等しい。

- 槽外周壁の外側表面から $1 \mathrm{~m}$ の地中土倳温度は一定 である。

・槽上部の床上の室温は一定である。

・断熱材と槽上部空気の熱容量は無視できる。

・槽外周部槽壁と土壌の間の熱抵抗は無視できる。

計算に用いた各種熱定数を表 2 に示す。以上の仮定と式を 用いて数値計算を行い、蓄熱槽への低温側・高温側入力温 度、それぞれの流量、そして全 26 槽のうち8槽の水温の 1 時間毎のデータを異常検知のためのデータとした。シ ミュレーションによる検討では、このデータを測定データ と呼んでいる。測定データ、生成のシミュレーションは、槽 内温度 $11{ }^{\circ} \mathrm{C}$ 一様加ら始めて、冷凍機の運転を 16 時から翌 日 13 時の 21 時間運転とし、冷房負荷は 8 時から 18 時の 10 時間を想定して8日間のシミュレーションを行い、8.日目 の 24 時間分のデータを測定データとした。異常条件のシ ミュレーションは、8日目の0 時に異常が発生したと想定 して、8日目のみ異常条件下でシミュレーションを行い、 24 時間分の異常条件の測定データとした。

なお、シミュレーションで想定した槽壁のコンクリート の厚さについては、槽外周では $1.0 \mathrm{~m}$ 、隔壁では $0.1 、 0.6$ 、

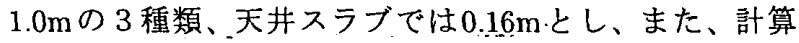
分割幅は土壤の場合と共に $0.02 \mathrm{~m}$ 、計算時間間隔は 3 分 間としている。図 2 に正常時における入力温度・冷凍機出 カ・冷房負荷の推移を、図3に槽内温度分布の推移を示し た。図4には、第10槽における各槽壁内部の温度分布の 推移を示した。

\section{（2）シミュレーションによる異常検知の検討}

データ生成シミュレーションでは全ての槽で $P_{i}=0.95$ と設定し、槽の異常としては、断熱材異常、水位異常、温 度センサ異常などを以下のように想定した。

- 第10槽で全断熱材破断

- 全ての槽の天井部分の断熱材破断

- 全ての槽で全断熱材破断

- 水位の異常低下 $(P=0.8)$

- 温度センサ異常のため第11槽で異常水温（正常時の 水温 $+3{ }^{\circ} \mathrm{C}$ ) 

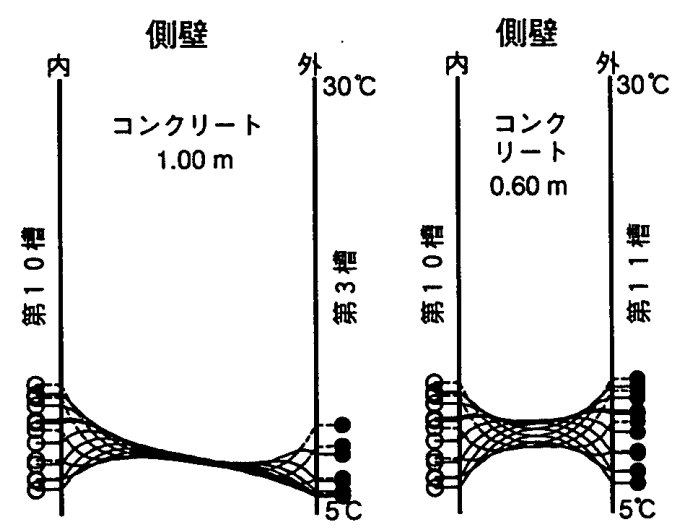

底部

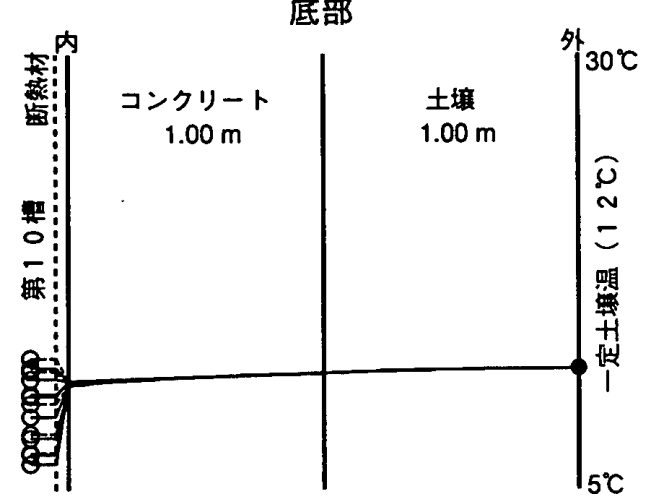

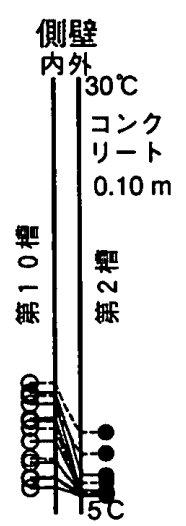

天井

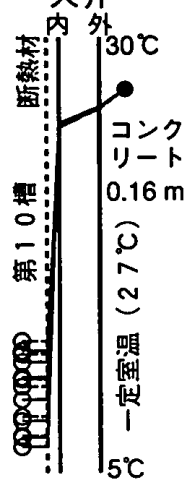

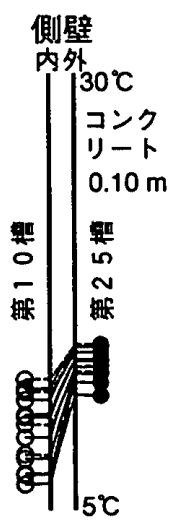

○ 水温

- 境界温度

蓄熱モード

放熱モード

図 4 正常時の第 10 槽槽壁内部の温度分布の推移

第 10 槽と周囲隣槽の位置関係

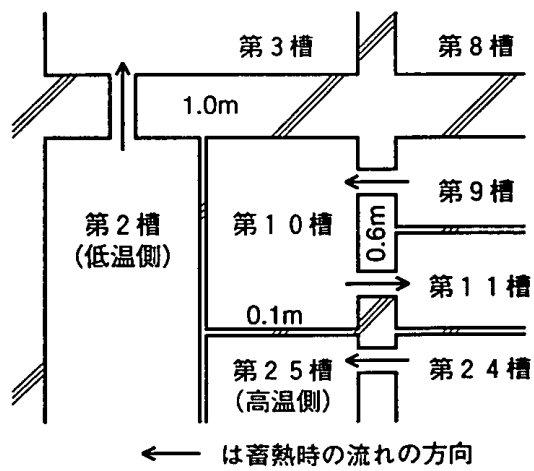

500

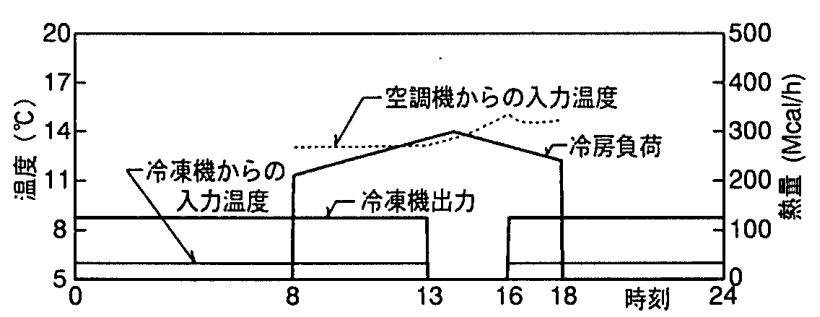

図 2 正常時の入力温度・冷凍機出力・冷房負荷の推移

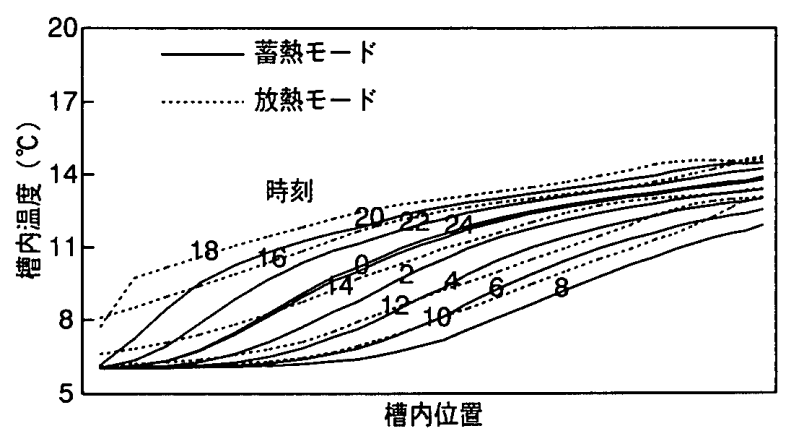

図 3 正常時の槽内温度分布の推移

ここで、断熱材破断とは断熱材がなくなっていることを 意味している。表 3 に、正常時を含め、種々の異常につい てパラメータ同定を行った結果を示したが、以下に要点 を示す。

・第 10 槽だけの断熱材破断のみでは正常時とほとんど 差がない。
表 3 同定結果一覧

\begin{tabular}{lccrr}
\hline 異常条件 & $P$ & $U A^{* 1}$ & \multicolumn{1}{c}{$q A^{* 2}$} & $\theta_{\text {ave }}^{* 3}$ \\
\hline 正常 & 0.953 & 505 & 66 & 10.5 \\
第 10 槽断熱材全破断 & 0.953 & 512 & 75 & 10.5 \\
全槽天井断熱材破断 & 0.952 & 530 & 282 & 10.7 \\
全槽全断熱材破断 & 0.965 & 683 & 266 & 10.8 \\
水位低下 $(P=0.80)$ & 0.802 & 437 & 62 & 10.5 \\
第 11 槽温度センサ異常*4 & 0.912 & 818 & 171 & 10.6 \\
槽壁熱損失無視 & 0.933 & 317 & 33 & 10.4 \\
\hline$* 1:\left[\mathrm{kcal} /\left(\mathrm{h} \cdot{ }^{\circ} \mathrm{C}\right)\right]$ & $* 2:[\mathrm{kcal} / \mathrm{h}]$ & $* 3:\left[{ }^{\circ} \mathrm{C}\right]$ & $* 4:$ 測定值 $+3\left[{ }^{\circ} \mathrm{C}\right]$
\end{tabular}

- 全槽天井断熱材破断の場合には定常熱取得 $q A$ が顕著 に増大する。

- 全槽全断熱材破断の場合でも周期的吸放熱に関係す るUAはそれほど増大しない。

- 水位低下は有効容積率 $P$ の変化として容易に検知で きる。

-センサ異常は断熱材破断と良く似た同定結果とな る。

-日平均蓄熱温度（槽内平均温度） $\theta_{\text {ave }}$ は、断熱異常の 段階に応じて、 $0.0 \sim 0.3{ }^{\circ} \mathrm{C}$ 程度上昇している。

図 5 に、第 10 槽での正常時と全断熱材破断時の熱取得 の時間推移の比較の例を示した。同定パラメータによる 

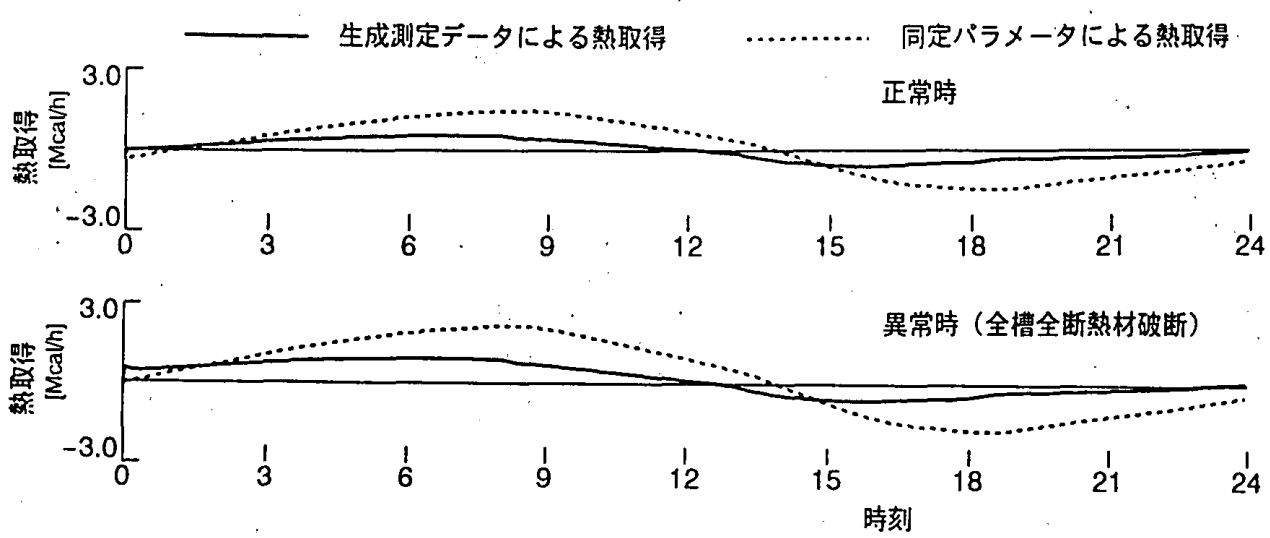

図 5 第 10 槽での正常時と全断熱材破断時の熱取得の時間推移の比較

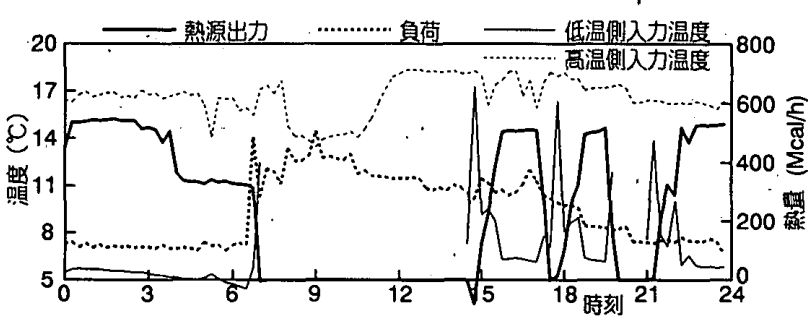

図 6 入力温度・冷凍機出力・冷房負荷の推移 $(8 / 12)$

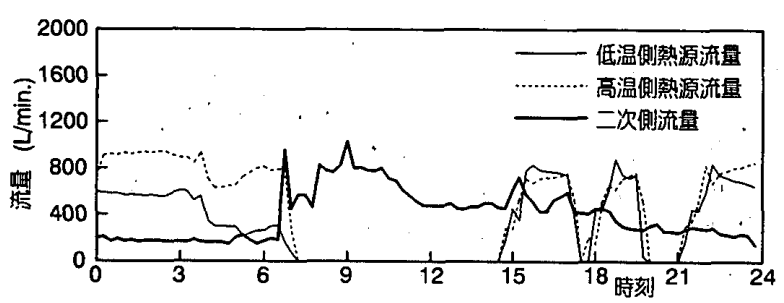

図 7 各種流量の推移 $(8 / 12)$

\begin{tabular}{|c|c|}
\hline 所在地 & 東京都 \\
\hline 構造 & 鉄骨鉄筋コンク.リート造 \\
\hline 延床面積 & (建築面積 $2404 \mathrm{~m}^{2}$ ) \\
\hline 階数 & 地上 4 階 - 地下 1 階 \\
\hline 主要用途 & 事務所 \\
\hline 熱源設備 & $\begin{array}{l}\text { 熱回収型空気熱源ヒートポンプ } \\
\text { 空気熱源ヒートポンプ } \\
\text { 泠房尃用空冷チラー }\end{array}$ \\
\hline 空調設備 & $\begin{array}{l}\text { 単一ダクトVAV方式 (一般系統) } \\
\text { 単一ダクト+FCU方式 (特殊系統) }\end{array}$ \\
\hline 蓄熱槽 & 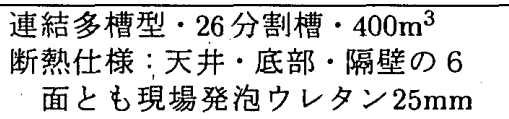 \\
\hline
\end{tabular}

熱取得の振幅が生成測定データより大きく、位相が少し 遅れているが、これはパラメータ同定用蓄熱槽モデルに おける槽壁との熱のやり取りがかなり簡易化され、槽壁 の熱容量を無視した定常熱伝導を仮定してモデル化され ているためである。この影響が何らかの形で同定誤差と して現れていると思われるが、ここでの同定結果を見る 限りでは、断熱材破断の場合には熱取得の振幅がかなり

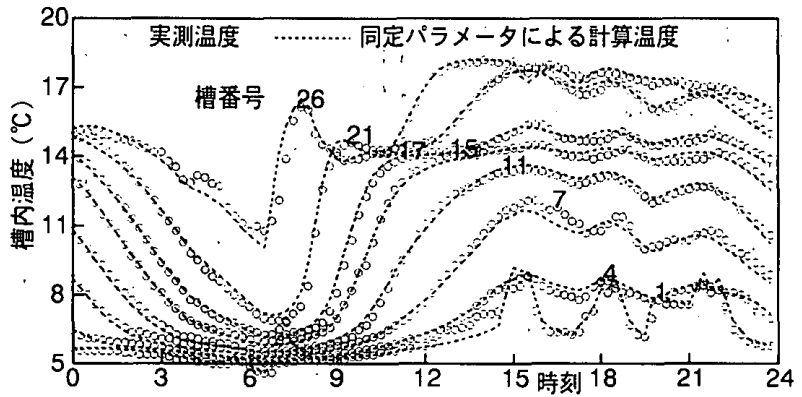

図 8 同定・実測槽内温度の推移 $(8 / 12)$

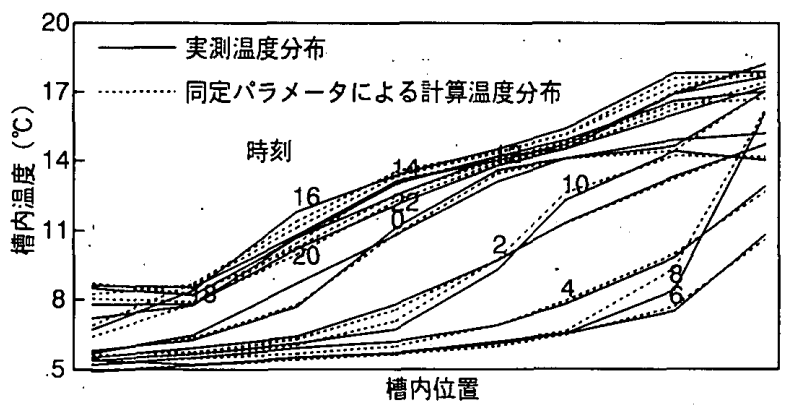

図 9 同定・実測槽内温度分布の推移 $(8 / 12)$

大きくなっており、異常検知に際して大きい影響はない ようである。

\section{5. 実システムの実测データによる同定}

分割槽数 26 の蓄熱槽を持つ熱源 3 系統・二次側 3 系統 の実システムの測定結果を用いてパラメータの同定を行 った。表 4 に実システムの概要を示した。直接実測されて いない入力温度については、各系統の流量により重みを 付けて平均温度を算出して用い、熱源の高温側・低温側 流量については、熱源入口温度と流量、および蓄熱槽の. 高温側・低温側汲上槽水温とそれぞれの流量の関係から 推定した。

\section{(1) パラメータ同定結果の分析}

同定例として、8月12日についての詳細を図6〜 9に示 した。それぞれ、実測データから推定した入力温度と冷 

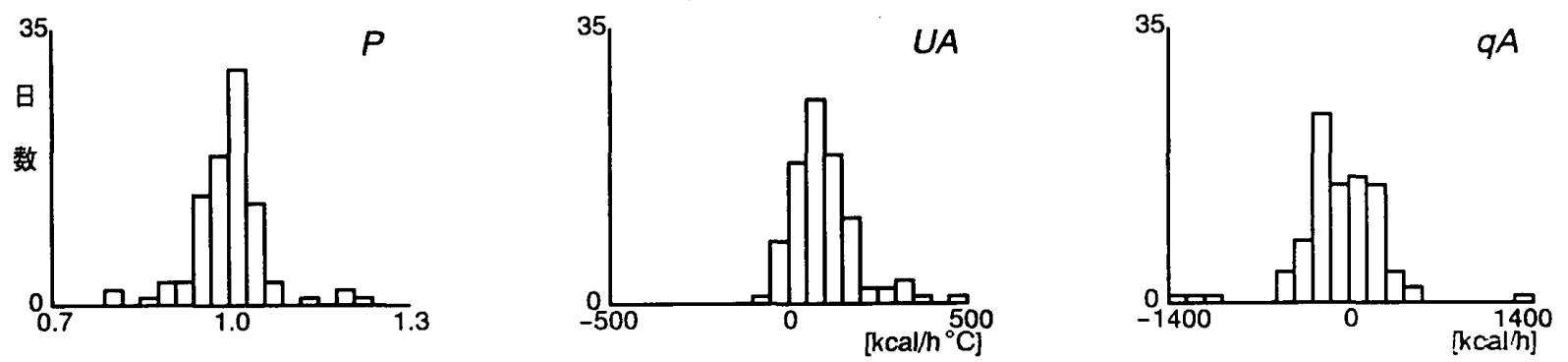

図 10 実測データによる同定パラメータ值の度数分布（1989年7〜9月）
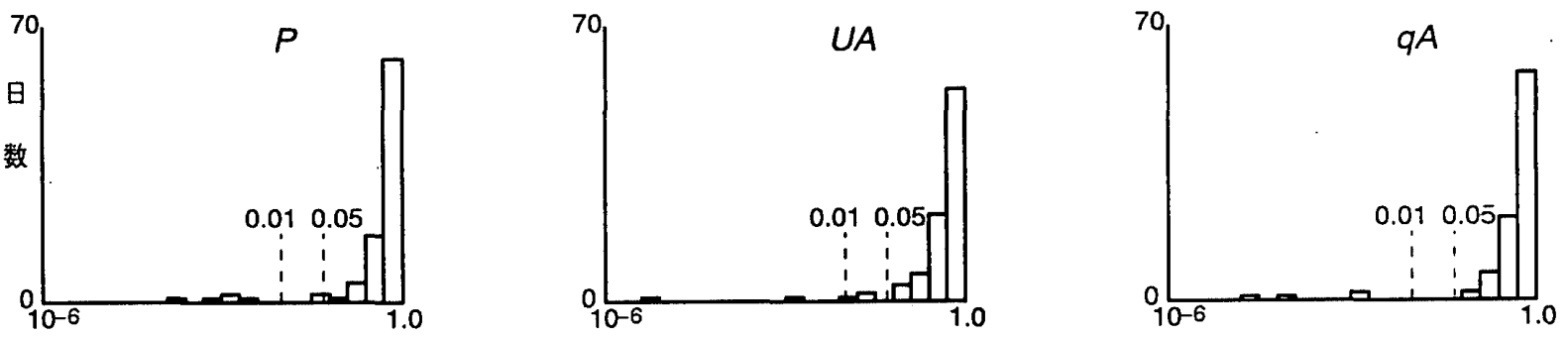

図 11 トンプソンの衰却検定における有意水準の度数分布（1989年7〜9月）
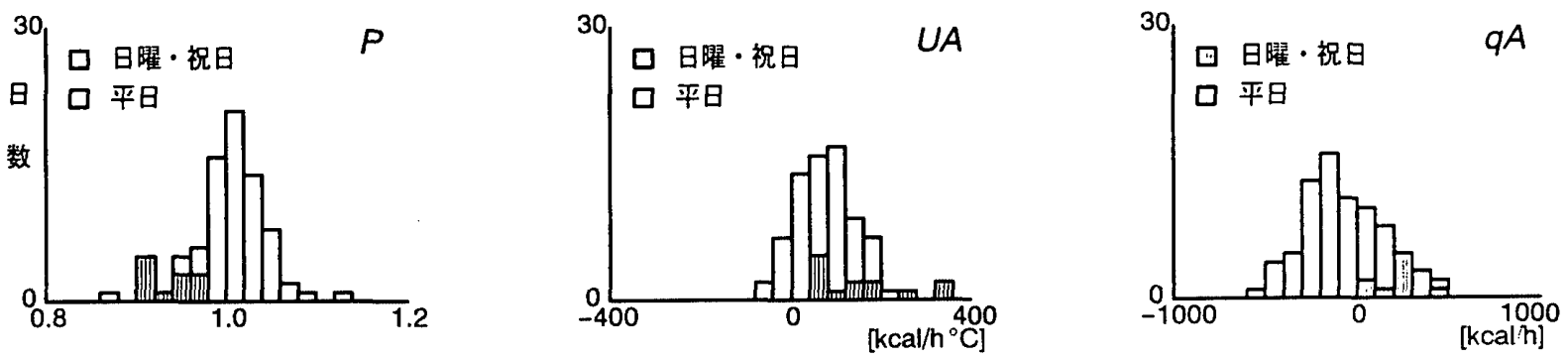

図 12 日曜・祝日と平日の同定パラメータ值の度数分布（1989年7 9月）

凍機出力・冷房負荷、流量、および槽内水温の時間変化 と分布に関する同定パラメータによる計算結果と実測結 果の比較である。

1989 年 7 月 9 月の 3 カ月 92 日分の実測データによる 同定結果を度数分布として图 10 に示した。想定システム での同定結果（表3）に比べて、壁体との吸放熱に関係す るUAが全体的に小さくなっているのは、想定システムで は隔壁は断熱なしとしているのに対して実システムでは 隔壁も断熱されているためと考えられる。また、槽壁か らの定常的な熱取得に関係する $q A$ が全体的に若千負側 に偏っているのは、実システムの蓄熱槽上部の室温が想 定システムの場合 $\left(27^{\circ} \mathrm{C}\right)$ より低温である可能性も考え られるが、熱取得が負になるとは考えにくく、同定值の ばらつきがかなり大きいことも考え合わせると同定誤差 と考えた方が良いと思われる。同定值にばらつきがある 場合に有効であると考えられる統計的検定によって異常

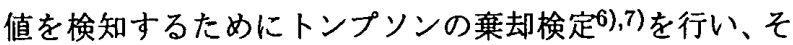
の有意水準の度数分布を図 11 に示した。

日曜や祝日は負荷が小さく平日とは運転状況が異なる と思われるので、日曜・祝日と平日に分けた同定パラメー 夕值の度数分布を図 12 に示した。日曜・祝日と平日の差
表 5 日曜・祝日と平日の差異の $t$ 検定結果 平均值 $t$ 值 有意レベル 日曜・祝日平日

\begin{tabular}{ccccc}
\hline$P$ & 0.932 & 1.010 & 8.09 & $1 \%$ \\
$q A^{* 1}$ & 269 & -96 & 6.34 & $1 \%$ \\
\hline$* 1:[\mathrm{kcal} / \mathrm{h}]$
\end{tabular}

異を統計的に検証するために $t$ 検定 6 (6)をを行った結果を表 5 に示したが、Pと $q A$ については $1 \%$ 有意で差があると いう結果となった。ただし、図 12 で用いた同定パラメー 夕值は、その分布を同定值全体の平均值と標準偏差を持 つ正規分布と仮定して両側 $1 \%$ を除外したものである。 これらの結果から、負荷などの諸条件と同定パラメータ 值との間に何らかの相関があると考えられ、高い相関倸 数が得られた結果の一部を图13に示した。図中rは相関 係数である。この結果から、Pについては、負荷が少なく 流量が小さいときに、そして蓄熱温度差が大きいときに 值が小さくなることから、浮力の効果で有効容積が减少 することが考えられる。 $q A$ については、槽内平均温度が 下がればそれだけ周囲からの熱取得が増大する傾向が現 れていると考えられる。 

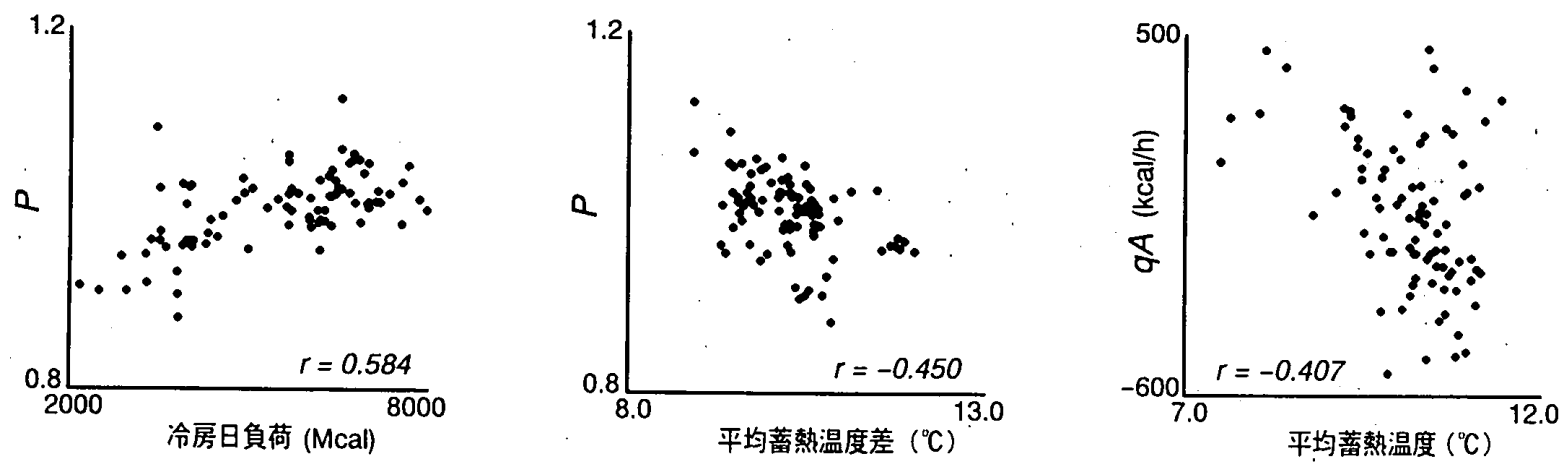

図 13 同定パラメータ值と日負荷・日平均蓄熱温度差・日平均蓄熱温度との関係（1989年7 9月）
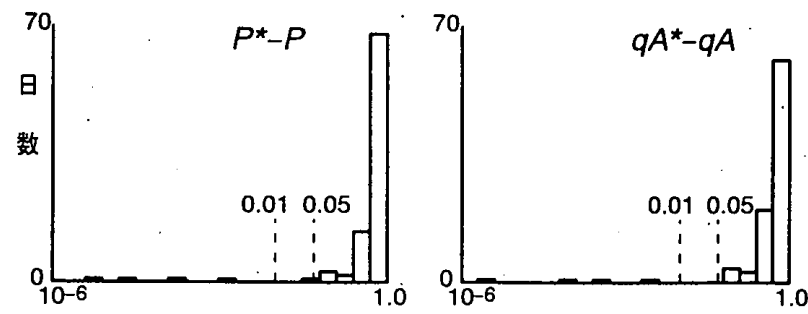

図 14 相関を考虑したトンプソンの㶳却検定における 有意水準の度数分布（1989年7〜9月.)

これらの相関を異常值の判定に組み入れるために以下 の回帰式を求めた。

$$
\begin{aligned}
P^{*} & =1.035-364.3\left(\Delta \theta_{\text {ave }} / Q_{\text {ave }}^{2}\right) \\
q A^{*} & =1178-120.4 \theta_{\text {ave }}
\end{aligned}
$$

ただし、回帰式を求めるために用いた同定パラメータ值 は、图12の場合と同様に両側 $1 \%$ を除外したものであ る。また、Pに関する回㷌式では浮力の影響を物理的に 代表する説明変数の形としている。この回帰式による推 定パラメータ值と同定值との差に関して、トンプンンの 谼却検定における有意水準を求め、その度数分布を図 14 に示した。この処理により検知レベルが向上し、.1\%有 意で異常值と判定される 4 日分のパラメー夕值を表 6 に 示した。Pと $q A$ において有意水準が $1 \%$ レベル以上とな る異常日では、原因が「不明」の1日を除いて、槽内温 度や入力温度の測定データの異常が原因であることが分 かった。

ここで同定に用いられたデータは、順調に稼働してい るシステムにおける測定データであるため、測定データ の異常のみの検知しかなされていないが、実システムの 測定データにより同定されたパラメータ值がある程度分 布していても、統計的なデータ処理と検定を利用するこ とにより異常検知が可能であることが明らかとなった。

\section{（2）断熱材の異常検知の検討}

シミュレーションによる異常検知で検討した断熱材の 破断に関しては、実システムのデータでは断熱材破断時 のデータば得られていないため、断熱材異常時に起こり

\begin{tabular}{lcccl}
\multicolumn{5}{c}{ 表 6 異常日のパラメータ值 } \\
\hline Date & $P$ & $U A^{* 1}$ & \multicolumn{1}{c}{$q A^{* 2}$} & \multicolumn{1}{c}{ 異常の原因 } \\
\hline $7 / 14$ & 1.205 & 305 & -1082 & 測定データの異常 \\
$7 / 31$ & 0.800 & 498 & 1273 & 不明 \\
$9 / 14$ & 1.185 & 191 & -1352 & 測定データの異常 \\
$9 / 15$ & 1.233 & 397 & -1137 & 測定データの異常 \\
\hline$* 1:\left[\mathrm{kcal} /\left(\mathrm{h} \cdot{ }^{\circ} \mathrm{C}\right)\right]$ & $* 2:[\mathrm{kcal} / \mathrm{h}]$ &
\end{tabular}

得る槽内温度上昇を模擬したデータを実測データから作 成した。ここでは 8 月の実測槽内温度から、断熱材破断

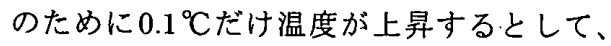

$$
\text { 異常時槽内温度 }=\text { 測定槽内温度 }+0.1 \quad\left[{ }^{\circ} \mathrm{C}\right]
$$

のように断熱材異常時のデータを作成した。これは、想 定システムの結果（表3）を参考にして、おおよそ、全槽 の天井断熱材破断の場合に相当するような槽内温度上昇 としたものである。

熱椇失に関係する $q A$ について、7 月の正常時の同定結 果につづいて 8 月の異常時と正常時の同定結果を図 15 に 示した。これから、同定された $q A$ の值の正常時と断熱材 異常時の差異は比較的小さく、毎日の同定值を比較した だけでは異常検知が困難なことが明らかであり、ここで は、統計的な検定手法である $t$ 検定を応用した異常検知 を検討した。

7 月と 8 月の同定された $q A$ をある境界日を境にして その境界日より以前の日のグループと境界日を含む以後 の日のグループの 2 グループに分割し、両者のグループ の平均値に差がないという仮説を棄却できる、すなわち、 両者のグループの平均值に差があるといえる場合の有意 レベルを算出した。图16に、設定された分割境界日を1 日づつずらしたときの有意レベルの変化を示したが、断 熱材異常が発生した 8 月 1 日を境にして正常日と異常日 が完全に二分されるため、8月 1 日を境界日にしたとき に最も有意レベルが高くなっており、断熱材の異常が検 知できたことになる。

現実の断熱材異常時のデータによる検討ができていな 


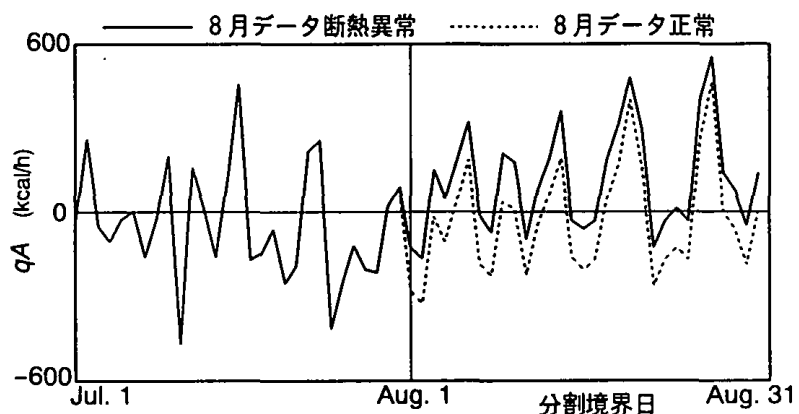

図 15 正常時と断熱異常時の $q A$ の変化

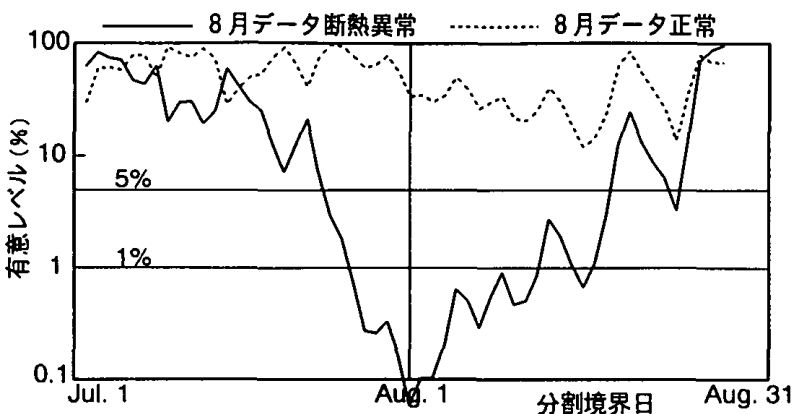

図 $16 t$ 検定の有意レベルの変化

いが、同定パラメータにある程度の差異が現れれば、統 計的検定により断熱材の異常についても検知できる可能 性を示せたと考えている。

\section{6. おわりに}

連結完全混合槽型蓄熱槽を用いた蓄熱システムに関し て、蓄熱槽自身の断熱材や水位の異常を自動的に検知す ることを目的として、蓄熱槽の物理モデルのパラメータ を計測データから同定することにより、その動特性の変 化を観察して異常検知を行う方法をシミュレーションお よび実システムの計測データにより検討した結果を示し た。

本研究をまとめると以下の通りである。

1. 槽壁との熱のやり取りを、壁体とのサイクリックな 吸放熱に関係する部分と定常的に熱が一方向に流れ る部分に分離した異常検知のための蓄熱槽物理モデ ルを示し、測定データから蓄熱槽モデルのパラメー タを同定することにより異常検知を行う方法と手順 を示した。

2. 槽壁の伝熱を一次元熱伝導と仮定してモデル化した シミュレーションを利用して異常データを発生させ ることにより、槽の水位異常や断熱材異常などの検 知の可能性を検討した。

3. 実蓄熱システムの実測データを用いてパラメータ同 定を行った結果を示し、同定パラメータと種々の運転 状況との相関関係を考慮して、異常検知をトンプン
ンの棄却検定を利用して行い、計測データの異常が 検知できることを示した。

4. 断熱材の異常検知の検討のために実測データを利用 して断熱材異常時のデータを作成し、同定パラメー 夕の変化を $t$ 検定を応用した方法で検知することに より異常検知が可能であることを示した。

蓄熱槽の断熱材異常は重大な事態ではあるが、そう頻 繁に発生することはないと思われ、また、シミュレーショ ンによる検討結果に示したように、一つの槽のみの断熱 材異常の検知は困難であるなどの問題点は残されている が、水位の低下や温度センサー異常などの検知について は比較的容易であることが明らかとなった。また、槽内 水温の測定点が少なくても、パラメータ同定されたモデ ルの利用により時々刻々の槽内温度分布を推定すること が可能であり、槽内温度分布の推移に影響が現れる制御 系の異常などの検知 ${ }^{8)}$ に利用寸ることも可能となると考 えている。

\section{解辞}

本研究は、国際エネルギー機関（IEA）Annex 25 の国 際共同研究「空調設備の最適化と異常検知・診断の研究」 の一環として行ったものであり、中原信生委員長（名古 屋大学) ほか関係各位および実蓄熱システムの計測デー 夕を提供いただいた（株）東京電力に謝意を表します。

魢号

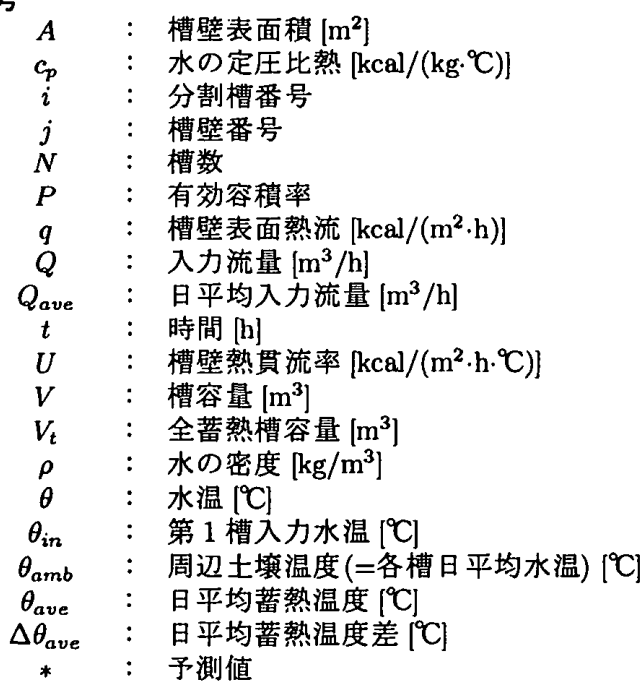

\section{本論文に関連する既発表論文}

1. 相良和伸: 連結多槽型蓄熱槽の異常検知・診断法のシミュ レーションによる検討、日本建築学会東海支部研究報告、 第31 号、pp.441 444、1993.2

2. 相良和伸 : 連結多槽型蓄熱槽の異常検知・診断法のシミュ レーションによる検討、日本建築学会大会学術諈演梗概 集、pp.1659 1660、1993.9

3. 相良和伸:連結多槽型蓄熱槽の異常検知・診断法の検時、空 気調和・衛生工学会学術講演会講演論文集、pp.393 396、 
1993.10

4. 相良和伸：動的物理モデルを用いた連結多槽型蓄熱槽の 異常検知・診断法の検討、日本建築学会東海支部研究報 告、第32号、pp.397 400、1994.2

5. 相良和伸：連結多槽型蓄熱槽の異常検知・診断法の実測 データによる検討、日本建築学会大会学術講演梗概集、 pp.907 908、1994.9

\section{参考文献}

1. 中原信生：BOF D（ビル最適化とフォルト検知）の概 念設計、日本建築学会東海支部研究報告集、第 30 号、 pp.281 284、1992.2

2. 高橋惊・伊東民雄・柴田克彦・清水昭浩: 空調設備異常予知 診断エキスパートシステム、空気調和·衛生工学、Vol.66、
No.12、pp.47 56、1992.12

3. 焼山誠・宮崎友昭・竹井宏：B E M Sにおけるシステム監 視と動作検証手法の研究、日本建筑学会大会学術講演梗 概集、pp.1747〜1750、1993.9

4. 国際エネルギー機関 (IEA) Annex 25 : Building Optimisation and Fault Diagnosis System Concept, 1993.10

5. 嘉納秀明:システムの最適理論と最適化、コロナ社、1987.1

6. 石村貞夫 : 統計解析のはなし、東京図書、1989.4

7. 黒瀬・松島・松尾：C言語による科学技術計算サブルーチ ンライブラリ、啓学出版、1986.11

8. 鄭明傑・中原信生:空調システムフォルトの動的シミュレー ション その 6 パターン認識による蓄熱システムフォル 卜の㭘知に関する研究、空気調和・衛生工学会学術講演 会講演論文集、pp.1113 1116、1994.10

（1994年10月26日原稿受理，1995年 5 月29日採用決定） 